\title{
DOSE-RELATED GENOTOXIC EFFECT OF T-2 TOXIN MEASURED BY COMET ASSAY USING PERIPHERAL BLOOD MONONUCLEAR CELLS OF HEALTHY PIGS
}

\author{
Katalin HORVATOVICH ${ }^{1}$, Dóra HAFNER ${ }^{1}$, Zsófia BODNÁR ${ }^{1}$, Gergely BERTA ${ }^{3}$, \\ Csaba HANCZ ${ }^{1}$, Mike DutTON ${ }^{4}$ and Melinda KovÁCS ${ }^{1,2^{*}}$ \\ ${ }^{1}$ Department of Animal Physiology and Hygiene, Kaposvár University, Guba S. u. 40, \\ H-7400 Kaposvár, Hungary; ${ }^{2}$ MTA-KE Mycotoxins in the Food Chain Research Group, \\ Kaposvár, Hungary; ${ }^{3}$ Department of Medical Biology, University of Pécs, Pécs, Hungary; \\ ${ }^{3}$ Faculty of Health Sciences, Doornfontein Campus, University of Johannesburg, \\ Doornfontein, Gauteng, South Africa
}

(Received 23 May 2012; accepted 27 September 2012)

T-2 toxin is the most acutely toxic trichothecene mycotoxin: it inhibits protein, DNA and RNA synthesis. The main goal of this study was to evaluate the rate of DNA damage caused by T-2 toxin in porcine mononuclear cells in increasing concentrations $(0.1,0.5$ and $1.0 \mu \mathrm{mol})$ and after two different incubation periods ( 24 and $42 \mathrm{~h}$ ). The lowest concentration caused DNA damage and about $50 \%$ of the treated cells could be categorised as having 1 to 4 scores in comet assay. In parallel with the increase of T-2 toxin concentration, the frequency of intact lymphocytes decreased from $50.2 \%(0.1 \mu \mathrm{M})$ to $36.3 \%(1.0 \mu \mathrm{M})$ in the first $24 \mathrm{~h}$. In case of score 3, the highest concentration of T-2 toxin resulted in a 5-fold change, as compared to the lowest dose. Cells with score 4 were found only after exposure to $1.0 \mu \mathrm{M} \mathrm{T}-2$ toxin. The exposure time did not have a significant effect on the results, while concentration did $(\mathrm{P}<0.0001)$. However, a significant interaction between concentration and time as fixed factors $(\mathrm{P}<0.0001)$ was found. When these were combined as a single factor, the results showed a significant toxin treatment effect on the results. It was concluded that a time- and dose-dependent DNA damaging effect of T-2 toxin could be demonstrated using peripheral blood mononuclear cells from healthy pigs by comet assay. cells

Key words: T-2 toxin, DNA damage, comet assay, pig, blood mononuclear

Mycotoxins are toxic fungal metabolites, which - when ingested, inhaled or absorbed through the skin - may induce varying undesirable health effects. Because of their unusual chemical structure and different toxicological characteristics, the effects and clinical signs caused by mycotoxins are very diverse

*Corresponding author; E-mail: kovacs.melinda@ke.hu; Phone: 0036 (82) 505-800; Fax: 0036 (82) 505-970 
(Njobeh et al., 2010). Many toxicological studies performed in vitro and in vivo to investigate the role of mycotoxins show evidence that several of them are involved in the aetiology of certain pathological conditions. Mycotoxins can induce cytotoxic, nephrotoxic, hepatotoxic, neurotoxic, carcinogenic, mutagenic, immunosuppressive and oestrogenic effects in animals and humans (Jaradat, 2005; Krska et al., 2007).

$\mathrm{T}-2$ toxin is a naturally occurring, toxic secondary fungal metabolite belonging to the group of A-type trichothecenes produced by Fusarium species (Krska et al., 2001; Langseth and Rundberget, 1998). It is widespread particularly in the temperate zone and has been described to correlate with various diseases in domestic animals, like reduced feed intake, vomiting, diarrhoea, haemorrhagic toxicosis, neural disturbances and skin irritation (Kuiper-Goodman et al., 1987; SchuhmacherWolz et al., 2010). The immunotoxicity of T-2 toxin was demonstrated in the study of Rafai et al. (1995), which was the central study for the derivation of the provisional maximum tolerable daily intake (PMTDI) and the temporary tolerable daily intake (t-TDI).

T-2 toxin was associated with a non-contagious haematological disease called alimentary toxic aleukia (ATA) that results in the destruction of the bloodforming tissues and often leads to death (Beardall and Miller, 1994). The pattern of oxygenations, acetylations or esterifications on the core trichothecene chemical structure (Meek et al., 2003) influences the degree of toxicity and makes the toxin one of the most toxic metabolites of the A-type trichothecenes that inhibit DNA and protein synthesis in eukaryotic cells (Ehrlich and Daigle, 1985; Holme et al., 2003). The 12,13-epoxide ring is essential for the toxicity of these mycotoxins, and removal of this ring results in a significant loss of toxicity (Varga and Tóth, 2005). Cytotoxic effect on lymphoid cells and induction of DNA single strand breaks in lymphoid and non-lymphoid cells have been associated with T-2 toxin (Lafarge-Frayssinet et al., 1981; Venkatesh et al., 2005). T-2 toxin was found to induce apoptotic cellular lesions in mice (Ihara et al., 1997) and cause gene mutation in cultured rodent cells, but it did not show DNA-damaging or gene-mutation-inducing effects in bacteria (Cooray and Jonsson, 1990).

Recent research has shown that both DON and T-2 toxin cause DNA fragmentation in chicken spleen leukocytes (Frankič et al., 2006) in vivo and in Caco-2 and Vero cell lines in vitro (Bony et al., 2006; Bouaziz et al., 2006). However, the exact mechanisms involved in the genotoxicity of trichothecenes are not yet completely clear, and no data are available in the literature about the genotoxic effect of T-2 toxin due to the activation of oxidative pathways or the formation of DNA adducts or direct double/single strand DNA breaks in animals such as pigs.

In recent years, the alkaline comet assay (single cell gel electrophoresis, SCGE), which was first described by Östling and Johanson (1984), has become a widely used tool in genetic toxicology. According to the guidelines for in vitro 
genotoxicity testing (Tice et al., 2000) any eukaryote cell can theoretically be used in the comet assay; however, for most purposes well-characterised cell lines or primary cells (e.g. human lymphocytes) are preferred.

The main goal of this study was to investigate the dose- and time-dependent genotoxic effect of T-2 toxin in comet assay, using peripheral blood mononuclear cells (lymphocytes) as target cells, isolated from healthy pigs. A further objective was to see whether the lymphocytes of healthy pigs would be sensitive enough to show the DNA-damaging effect of T-2 toxin when they are exposed to the toxin in vitro.

\section{Materials and methods}

\section{Chemicals}

All chemicals used in this study were obtained from Sigma-Aldrich Ltd. (Budapest, Hungary). Specialised chemicals used were: Histopaque-1077, RPMI1640 medium, and 4',6-diamine-2-phenylindol dihydrochloride (DAPI) for staining. The T-2 mycotoxin standard used in this study was purchased from Sigma (St. Louis, Missouri, USA).

\section{Isolation and purification of mononuclear cells}

Venous blood from a healthy pig (a 4-month-old growing castrated Hungarian Large White pig of $24 \mathrm{~kg}$ body weight) was mixed with an equal volume of RPMI-1640 tissue culture medium. The mixture was overlaid on Histopaque1077 and centrifuged at $3000 \mathrm{rpm}$ for $30 \mathrm{~min}$, then the interface layer consisting of mononuclear cells was carefully removed with a sterile pipette. The mononuclear cells (lymphocytes) were washed 3 times with $15 \mathrm{ml} \mathrm{RPMI-1640}$ and each time centrifuged at $3000 \mathrm{rpm}$ for $10 \mathrm{~min}$. Finally, the pelleted cells were resuspended in $10 \mathrm{ml}$ of RPMI-1640 medium.

The experimental protocol was authorised by the Food Chain Safety and Animal Health Directorate of the Somogy County Agricultural Office, under permission number 23.1/02322/007/2008.

\section{Exposure to T-2 mycotoxin}

Before the addition of T-2 toxin, cell counts were done as follows: cell suspensions $(100 \mu \mathrm{l})$ were mixed with $100 \mu \mathrm{l}$ of $0.4 \%$ Trypan Blue solution in an Eppendorf tube and incubated for 5-10 $\mathrm{min}$ at room temperature. A small amount of the Trypan Blue-cell suspension mixture was transferred to both chambers of a Neubauer counting chamber (haemocytometer) with a cover glass in place using a sterile Pasteur pipette. The cell viability (\%) was calculated as total number of viable cells $\times 100 /$ total number of viable plus non-viable cells. The cell count was adjusted to $5 \times 10^{6} / \mathrm{ml}$ ( $95 \%$ cell viability). The suspension 
$(100 \mu \mathrm{l})$ was transferred to plastic tissue culture plates and $100 \mu \mathrm{l}$ T-2 toxin stock solution (prepared with ethanol and diluted with redistilled water) was added to the suspension to give final concentrations of $0,1 \mu \mathrm{M}, 0,5 \mu \mathrm{M}$ and $1 \mu \mathrm{M}$ of T-2 toxin in a final volume of $200 \mu \mathrm{l}$. As control, isolated lymphocytes were placed in wells containing redistilled water and ethanol to the same volume as the test. The cell suspensions exposed to mycotoxin were incubated at $37{ }^{\circ} \mathrm{C}$ in a $5 \% \mathrm{CO}_{2}$ humidified incubator for 24 or $42 \mathrm{~h}$.

\section{Comet assay}

One percent normal melting point (NMP) agarose was prepared by dissolving $0.5 \mathrm{~g}$ in $50 \mathrm{ml}$ phosphate buffered saline (PBS) in a beaker and heating in a microwave oven until boiling, with occasional mixing until it completely dissolved. New slides were coated with warm 1\% NMP agarose gel prepared by dipping the slide vertically into gel in a beaker, and then they were allowed to dry overnight. About $140 \mu \mathrm{l}$ of $1 \%$ warm low melting point (LMP) agarose gel $\left(37^{\circ} \mathrm{C}\right)$ in PBS was prepared as above and was added to the incubated cells $(5 \times$ $10^{5}$ cells $\left./ 100 \mu 1\right)$. The suspension was mixed gently and quickly, then $70 \mu \mathrm{l}$ was transferred to two spots on the previously coated slides. The suspensions were covered with cover slips $(20 \times 20 \mathrm{~mm})$ and allowed to set for at least $10 \mathrm{~min}$ at $4{ }^{\circ} \mathrm{C}$. The coverslips were removed and cell membranes were lysed with lysis buffer solution ( $1 \%$ Triton X-100, $2.5 \mathrm{M} \mathrm{NaCl}, 10 \mathrm{mM}$ Tris, $0.1 \mathrm{M}$ EDTA, pH 10) for $1 \mathrm{~h}$ at $4{ }^{\circ} \mathrm{C}$. The resulting nucleic acids were unwound in alkaline electrophoresis buffer ( $\mathrm{pH}$ 13) in an electrophoresis tank (Cleaver Scientific Ltd., Warwickshire, UK) for $40 \mathrm{~min}$ at $4{ }^{\circ} \mathrm{C}$ and followed by electrophoresis at $25 \mathrm{~V}(300 \mathrm{~mA})$ for $30 \mathrm{~min}$ at $4{ }^{\circ} \mathrm{C}$. The slides were placed in neutralising buffer $(\mathrm{pH} 7.5)$ with 3 washes of $5 \mathrm{~min}$ each, and finally washed in redistilled water for $5 \mathrm{~min}$. The gels were allowed to dry overnight, stained with $30 \mu \mathrm{l}$ of DAPI working solution, and covered with coverslips. The confocal fluorescence images were generated using an Olympus Fluoview FV-1000 laser scanning confocal imaging system (Japan).

\section{Comet assay (DNA damage) scoring}

Manual scoring was done by following the methods of Singh et al. (1988) and Collins et al. (1997), in which comets are classified into scores of ' 0 ', ' 1 ', '2', ' 3 ' and ' 4 ' according to DNA damage and head/tail migration (Fig. 1). A minimum of 100 cells per samples were scored according to the move or shape of the comet that was formed (Hartmann et al., 2003). Each single comet was scored visually and assigned into an arbitrary unit from 0 to 4 depending on the relative intensity of DNA fluorescence in the tail. 

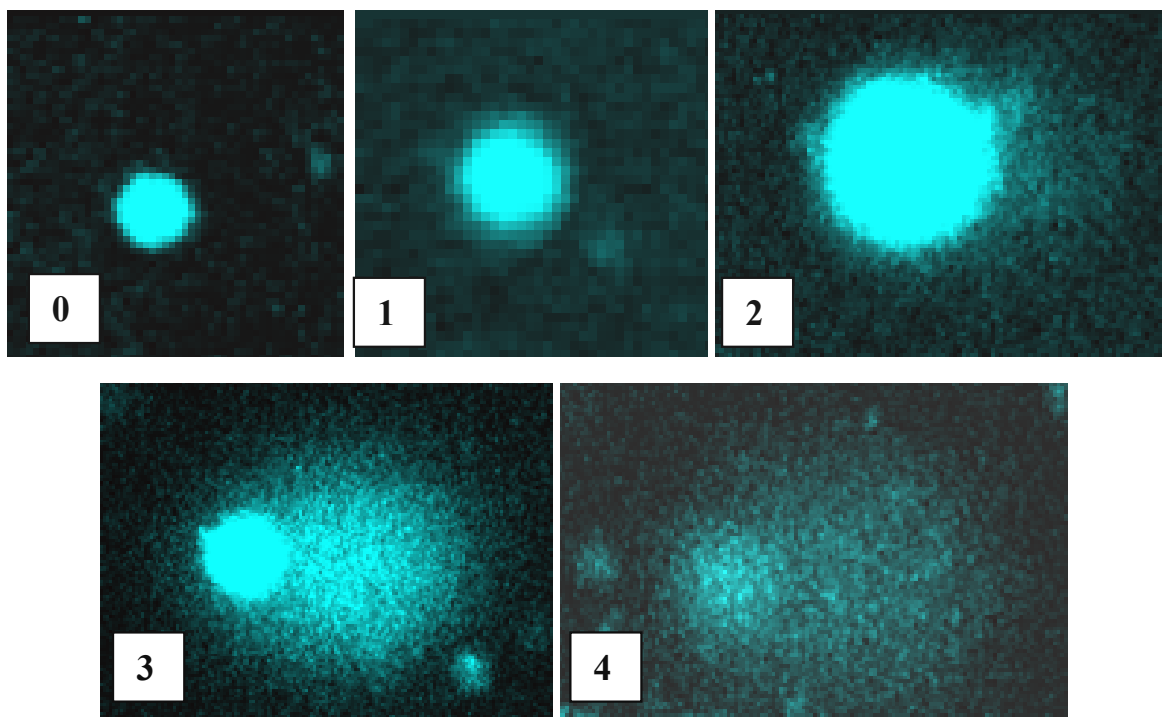

Fig. 1. Images of comets from pig lymphocytes stained with DAPI. They represent classes 0 to 4 as used for visual scoring

\section{Statistical analysis}

All statistical calculations were executed using the SPSS 19 software (SPSS Inc., Chicago, IL, USA). Examining the dataset with the Kolmogorov-Smirnov test, it was found that the data were not normally distributed. Therefore, between-group comparisons were performed with a non-parametric test (Lovell and Omori, 2008), the Kolmogorov-Smirnov Z comparison. These are indicated with uppercase indices in the bar graphs.

To explore the effects of toxin concentration and incubation time on the above differences, General Linear Model (GLM) evaluation was performed, the comet assay results taken as dependent, while toxin concentration and exposure time as fixed factors into the model. As we obtained a significant interaction between the two fixed factors $(\mathrm{P}<0.0001)$, exposure time and toxin concentration were expressed as a single factor (termed toxin treatment) in the further analysis, and data were evaluated in the next step by one-way analysis of variance.

\section{Results}

The combined effect of incubation time and concentration on the prevalence of cells with different comet values was examined. In the case of 24-h treatment, the cells with a comet assay score of 4 occurred only in samples with the highest $(1.0 \mu \mathrm{M})$ toxin concentration (Table 1). The number of cells with score 3 tended to increase from $0.1 \mu \mathrm{M}$ to $1.0 \mu \mathrm{M}$ concentration. Cells with score 2 
occurred in nearly similar proportions in case of the three doses. The prevalence of cells with score 1 was higher in samples treated with $0.5 \mu \mathrm{M}$ T-2 compared to $0.1 \mu \mathrm{M}$ and $1.0 \mu \mathrm{M}$ concentrations of the toxin. The frequency of cells with score 0 showed a similar rate in samples exposed to $0.5 \mu \mathrm{M}$ and $1.0 \mu \mathrm{M}$ of T-2, while in samples treated with the smallest toxin concentration $(0.1 \mu \mathrm{M})$ a higher value was observed.

Table 1

Comet assay values with respect to incubation time and concentration of T-2 toxin

\begin{tabular}{lcccccccc}
\hline $\begin{array}{l}\text { Concentration } \\
\text { of T-2 toxin }\end{array}$ & \multicolumn{3}{c}{ Incubation time $24 \mathrm{~h}$} & & \multicolumn{3}{c}{ Incubation time $42 \mathrm{~h}$} \\
\cline { 2 - 5 } \cline { 7 - 8 } & $0.1 \mu \mathrm{M}$ & $0.5 \mu \mathrm{M}$ & $1.0 \mu \mathrm{M}$ & & $0.1 \mu \mathrm{M}$ & $0.5 \mu \mathrm{M}$ & $1.0 \mu \mathrm{M}$ \\
\hline $0^{1}$ & $301^{3}$ & 237 & 218 & & 367 & 131 & 150 \\
Frequency $\%$ & 2 & 50.2 & 39.5 & 36.3 & & 61.2 & 21.8 & 25 \\
1 & 239 & 280 & 237 & & 203 & 303 & 365 \\
Frequency \% & 39.8 & 46.7 & 39.5 & & 33.8 & 50.5 & 60.8 \\
2 & 42 & 36 & 50 & & 30 & 163 & 77 \\
Frequency \% & 7.00 & 6.00 & 8.30 & & 5.00 & 27.2 & 12.8 \\
3 & 18 & 47 & 90 & & 0 & 3 & 8 \\
Frequency \% & 3.00 & 7.80 & 15.0 & & 0 & 0.50 & 1.30 \\
4 & 0 & 0 & 5 & & 0 & 0 & 0 \\
Frequency \% & 0 & 0 & 0.8 & & 0 & 0 & 0 \\
\hline
\end{tabular}

${ }^{1}$ values of comet scores $(0-4) ;{ }^{2}$ frequency of comet scores $(\%) ;{ }^{3}$ number of cells with the respective comet value

After 42-h incubation no cells were found with a comet assay score of 4 (Table 1). Higher concentrations of T-2 resulted in increased number of cells showing a score of 3, like in samples of the 24-hour treatment, but in a much lower frequency. The comet assay values of 2 showed the highest prevalence in samples treated with $0.5 \mu \mathrm{M}$ toxin, while the lowest value was observed in samples exposed to $0.1 \mu \mathrm{M}$. In the frequency of score 1 , the trend of a dosedependent increase was found. Cells with 0 values showed the highest prevalence in the samples exposed to the lowest toxin concentration $(0.1 \mu \mathrm{M})$.

When investigating the separate effect of incubation time, it was found that in samples with 42-h treatment, comet assay values 1 and 2 showed significantly higher frequencies as compared to 24-h treatment (Fig. 2). However, cells with comet assay values of 0 and 3 had lower frequencies in case of 42-h incubation, and comet score 4 was not found in these samples.

Testing the separate dose-dependent effect of T-2 toxin, the highest prevalence of 0 values was observed in samples exposed to $0.1 \mu \mathrm{M} \mathrm{T}-2$ (Fig. 3), while values 1,2 and 3 showed higher frequencies in samples treated with 0.5 and $1.0 \mu \mathrm{M}$ T-2 toxin than in those exposed to $0.1 \mu \mathrm{M}$ T-2 toxin treatment. Cells showing the greatest DNA damage (value 4) were observed only in samples treated with the highest $\mathrm{T}-2$ toxin concentration $(1.0 \mu \mathrm{M})$. 


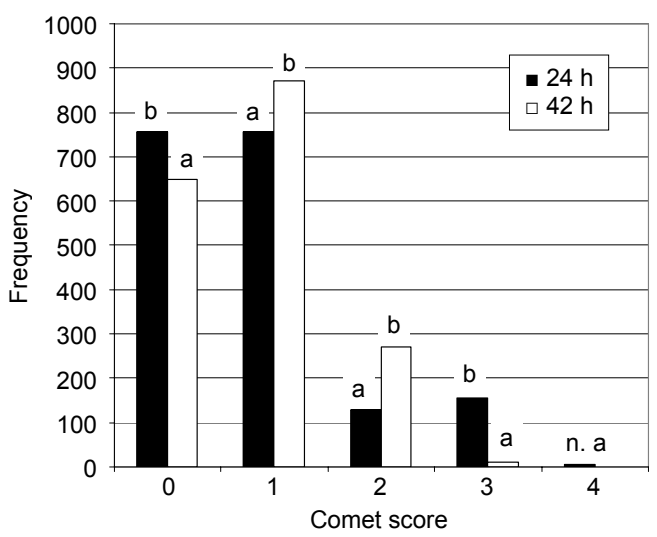

Fig. 2. Effect of incubation time on comet assay values. ${ }^{\text {ab }} \mathrm{P} \leq 0.05$ by Kolmogorov-Smirnov $\mathrm{Z}$ test; n. a.: not available

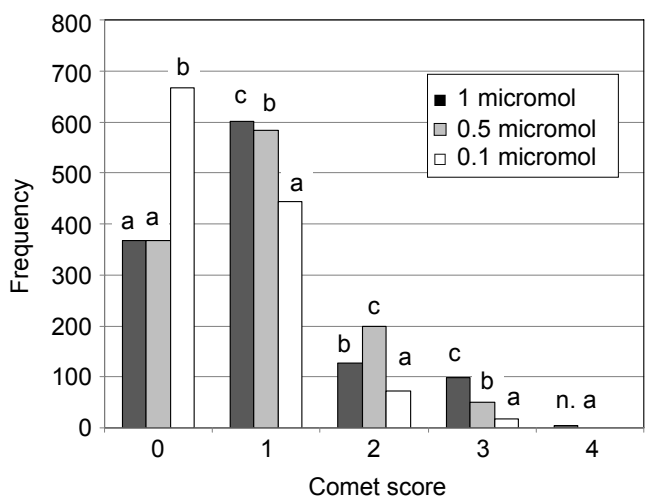

Fig. 3. Effect of concentration on comet assay values. ${ }^{\text {abc }} \mathrm{P} \leq 0.05$ by Kolmogorov-Smirnov $\mathrm{Z}$ test; n. a.: not available

The results of GLM analysis proved that exposure time had no significant effect $(\mathrm{P}=0.251)$ on the comet assay results, while concentration had $(\mathrm{P}<$ $0.0001)$. However, a significant interaction was found between the two fixed factors (dose and time) $(\mathrm{P}<0.0001)$. When we combined exposure time and toxin concentration as a single factor, one-way analysis of variance proved a significant toxin treatment effect on the comet assay results.

\section{Discussion}

To our knowledge, this is the first study in which the peripheral blood mononuclear cells of healthy pigs were used in the comet assay to detect the concentration- and time-dependent DNA-damaging effect of T-2 toxin. 
Various in vitro and in vivo studies have been conducted to assess the genotoxic potential of T-2 toxin. Lafarge-Frayssinet et al. (1981) detected severe damage of the DNA molecule in the spleen and thymic lymphocytes of BALB/c mice exposed to low concentrations $(5 \mathrm{ng} / \mathrm{ml})$ of T-2 toxin over a short exposure time $(2 \mathrm{~h})$ by using Parodi's alkaline elution technique coupled with a microfluorimetric determination of DNA. DNA fragmentation could be observed in chicken liver cells within $4 \mathrm{~h}$ after T-2 toxin application, which could be prevented by prior administration of the antioxidant vitamin $\mathrm{E}$, indicating that the formation of free radicals might be involved in the DNA damage (Jaradat et al., 2006; Weber et al., 2007).

In Hungary, farm animals are often exposed to mycotoxins, especially to Fusarium toxins, like the trichothecenes such as T-2 toxin. This often involves the combined effect of more than one mycotoxin in low doses but for longer exposure times. Trichothecene toxins may cause direct DNA strand breaks or modifications in the DNA base oxidation or methylation, which can alter gene expression and cell signalling, and consequently inhibit proliferation or even cause cell death (Chaudhari et al., 2009).

Since the first use of the comet assay, it has been widely applied in monitoring environmental genetic toxicology in humans, e.g. to investigate the impact of dietary factors on DNA stability (Hoelzl et al., 2009). A limitation is that the comet assay detects only DNA fragmentation and does not clarify the exact mechanisms responsible for the formation of DNA damage. Using this technique, one of our goals was to evaluate the rate of DNA damage caused by T-2 toxin in increasing concentrations and after two incubation periods ( 24 or $42 \mathrm{~h}$ ). We used $0.1,0.5$ and $1.0 \mu \mathrm{M}(46.6,233$ and $466 \mathrm{ng} / \mathrm{ml}) \mathrm{T}-2$ toxin concentrations, which can be found in normal human peripheral blood $(0.2-1800 \mathrm{ng} / \mathrm{ml})$ according to Berek et al. (2001). The tested concentrations were chosen by taking into consideration the data available in the scientific literature, i.e. data of different in vitro tests, summarised in the most recent scientific results of the European Food Safety Authority (Schuhmacher-Wolz et al., 2010). In that publication, inhibition of protein synthesis in mammalian cell cultures treated with T2 toxin in vitro was reported, with a concentration of $0.01 \mathrm{ng} / \mathrm{ml} \mathrm{T-2}$ toxin resulting in a $75 \%$ inhibition of viability in rat hepatocytes. Disaggregation of the polysomes was reported in HeLa cells treated with T-2 toxin at concentrations of 1-100 $\mu \mathrm{M}$ (Liao et al., 1976), whereas both DNA and RNA synthesis was inhibited by T-2 toxin in various cell lines at concentrations ranging from $>0.1$ to $\sim 10 \mathrm{ng} / \mathrm{ml}$. Increased reactive oxygen species (ROS) and malondialdehyde (MDA) levels with subsequently lower glutathione (GSH) levels were observed at the dose level of $10 \mathrm{ng} / \mathrm{ml} \mathrm{T}-2$ toxin in human cervical cancer cells in vitro. On the other hand, feeding of a diet contaminated with T-2 + HT-2 toxins increased the rate of lipid peroxidation as measured by MDA content, but only in the liver homogenate of chickens (Pál et al., 2009). Using two human cell lines (human renal 
proximal tubule epithelial cells and normal human lung fibroblast) in primary culture, cytotoxic effects were observed on exposure to T-2 toxin. From this treatment, IC50 values of 0.2 and $0.5 \mu \mathrm{M}$ revealed the strong cytotoxic effect on the cells and apoptotic cell death was already obvious at a concentration of $0.1 \mu \mathrm{M}$.

Our results are in agreement with the latter data, as even the lowest concentration of T-2 toxin used $(0.1 \mu \mathrm{M})$ caused DNA damage, and about $50 \%$ of the affected cells could be assigned into one of the categories from 1 to 4 in the comet assay. In parallel with the increase of mycotoxin concentration, the frequency of intact lymphocytes decreased from $50.2 \%(0.1 \mu \mathrm{M})$ to $36.3 \%(1.0 \mu \mathrm{M})$ in the first $24 \mathrm{~h}$, but no similar change in the frequency of cells assigned to scores 1 and 2 was observed. In case of score 3, the highest concentration resulted in a 5-fold frequency compared to the lowest dose. Cells characterised as score 4 were found only in case of $1.0 \mu \mathrm{M} \mathrm{T}-2$ toxin exposure.

T-2 toxin is supposed to have an acute genotoxic effect as reported by Giroir et al. (1991), who suggested that the highest genotoxic effect occurred within the first $24 \mathrm{~h}$ after a single orally administered dose of $0.5 \mathrm{mg} / \mathrm{kg} \mathrm{b}$.w. to chickens. Consequently, in this study we examined the rate of DNA damage caused to the cell by T-2 toxin after 24 and $42 \mathrm{~h}$ of exposure. The dose-dependent effect of the toxin was shown by the frequency of cells with scores 0,1 and 2 after 24-h exposure and also at the end of the 42-h incubation period. However, after the 42-h incubation period, the number of cells assigned into category 3 decreased, whereas an absence of comet values 4 was observed, probably because the longer incubation period resulted in completely disintegrated cells, which could not be counted. There is no obvious explanation as to why the lower breakage rated comets did not progress to comet values 3 or 4 .

The aim of this study was also to see if the lymphocytes of healthy pigs would be sensitive enough to show the genotoxic effect of T-2 toxin when they are exposed to T-2 toxin in vitro and to investigate the use of these cells as possible model systems, rather than cell cultures or human lymphocytes, for testing genotoxicity. Human lymphocytes have been widely used for in vitro exposure tests (Ré et al., 1997; Faust et al., 2004), but their application can be complicated because of the strict ethical considerations which have to be met and the species differences. Therefore, using the mononuclear cells of animals would be a useful alternative to human cells. Pigs seem to be a useful model for humans, because in many aspects they correlate better to human physiology than other animals and are known to be among the animal species most sensitive to mycotoxins (Huff et al., 1988; Hussein and Brasel, 2001). Furthermore, pig nutrition is based on cereals, which can contain considerable amount of mycotoxins, so besides poultry, pigs are the most frequently exposed farm animals. In a previous study, we found pig lymphocytes to be more sensitive to the cytotoxic effect of mycotoxins than human lymphocytes (Mwanza et al., 2009). Thus, using the lymphocytes of the same genotype, sex and age may provide homogeneous cells for the study, supporting 
the reproducibility of the test. Apart from the study mentioned above, there are no in vitro studies performed on cells derived from pigs which evaluated the genotoxic effect of T-2 toxin, although the comet assay has been used for other purposes, e.g. by Kruszewski et al. (2008). The work of Frankič et al. (2008) in an in vivo study showed that DON and T-2 toxin induced DNA damage in pig lymphocytes as measured by the comet assay, after feeding two groups of animals with feeds containing 4 and $3 \mathrm{mg} / \mathrm{kg}$ toxin, respectively. Similar results were obtained in experiments with chickens (Frankič et al., 2006; Sokolovic et al., 2008).

This study supports the suggestion that the comet test using pig lymphocytes from healthy animals may be used for estimating the time- and dosedependent genotoxicity of single and combined mycotoxins. Another approach of this method may be to use pig lymphocytes in the comet assay to screen extracts of agricultural commodities and food, testing if they are contaminated by any genotoxic substance; however, the results of the comet assay are not specific, and the potentially genotoxic compounds can be identified only by analytical methods. By using this approach, in many cases the time- and cost-demanding chemical analyses and/or animal experiments can be avoided. This suggestion was supported by the preliminary results of Maenetje et al. (2008), who used human lymphocytes in cytotoxicity testing and found that the methyl thiazole tetrazolium (MTT) test allowed screening of barley extracts containing deoxynivalenol (DON), ochratoxin A and fumonisin B1 mycotoxins.

In conclusion, the time- and dose-dependent DNA-damaging effect of T-2 toxin could be demonstrated in the comet assay, by using healthy pigs' peripheral blood mononuclear cells and exposing them in vitro to $0.1,0.5$ and $1.0 \mu \mathrm{M}$ toxin for 24 and $42 \mathrm{~h}$.

\section{Acknowledgements}

The research was funded by the Hungarian Scientific Research Fund (project no.: 100810) and the TÁMOP 4.2.1.B-10/2/KONV-2010-0002 project. The purchase of the Olympus Fluoview FV-1000 laser scanning confocal imaging system (Japan) was supported by grant GVOP-3.2.1-2004-04-0172/3.0 to the University of Pécs. We are grateful to Dr. András Szabó for his help in the statistical analyses.

\section{References}

Beardall, J. and Miller, J. D. (1994): Natural occurrence of mycotoxins other than aflatoxin in Africa, Asia and South America. Mycotox. Res. 10, 21-40.

Berek, L., Petri, I. B., Mesterházy, A., Téren, J. and Molnár, J. (2001): Effects of mycotoxins on human immune functions in vitro. Toxicol. In Vitro 15, 25-30.

Bony, S., Carcelen, M., Olivier, L. and Devaux, A. (2006): Genotoxicity assessment of deoxynivalenol in the Caco-2 cell line model using the comet assay. Toxicol. Lett. 166, 67-76. 
Bouaziz, C., Abid-Essefi, S., Bouslimi, A., El Golli, E. and Bacha, H. (2006): Cytotoxicity and related effects of T-2 toxin on cultured Vero cells. Toxicon 48, 343-352.

Chaudhari, M., Jayaraj, R., Bhaskar, A. S. and Lakshmana Rao, P. V. (2009): Oxidative stress induction by T-2 toxin causes DNA damage and triggers apoptosis via caspase pathway in human cervical cancer cells. Toxicology 262, 153-161.

Collins, A., Dusinská, M., Franklin, M., Somorovská, M., Petrovská, H., Duthie, S., Fillion, L., Panayiotidis, M., Raslová, K. and Vaughan, N. (1997): Comet assay in human biomonitoring studies: reliability, validation, and applications. Environ. Mol. Mutagen. 30, 139-146.

Cooray, R. and Jonsson, P. (1990): Modulation of resistance to mastitis pathogens by pretreatment of mice with T-2 toxin. Food Chem. Toxicol. 28, 687-692.

Ehrlich, K. C. and Daigle, K. W. (1985): Protein synthesis by mammalian cells treated with C-3modified analogs of the 12,13-epoxytrichothecenes T-2 and T-2 tetraol. Appl. Environ. Microbiol. 50, 914-918.

Faust, F., Kassie, F., Knasmüller, S., Boedecker, R. H., Mann, M. and Mersch-Sundermann, V. (2004): The use of the alkaline comet assay with lymphocytes in human biomonitoring studies. Mutat. Res. 566, 209-229.

Frankič, T., Pajk, T., Rezar, V., Levart, A. and Salobir, J. (2006): The role of dietary nucleotides in reduction of DNA damage induced by T-2 toxin and deoxynivalenol in chicken leukocytes. Food Chem. Toxicol. 44, 1838-1844.

Frankič, T., Salobir, J. and Rezar, V. (2008): The effect of vitamin E supplementation on reduction of lymphocyte DNA damage induced by T-2 toxin and deoxynivalenol in weaned pigs. Anim. Feed Sci. Technol. 141, 274-286.

Giroir, L. E., Ivie, G. W. and Huff, W. E. (1991): Comparative fate of the tritiated trichothecene mycotoxin, T-2 toxin, in chickens and ducks. Poult. Sci. 70, 1138-1143.

Hartmann, A., Plappert, U., Poetter, F. and Suter, W. (2003): Comparative study with the alkaline Comet assay and the chromosome aberration test. Mutat. Res. 536, 27-38.

Hoelzl, C., Knasmüller, S., Misík, M., Collins, A., Dusinská, M. and Nersesyan, A. (2009): Use of single cell gel electrophoresis assays for the detection of DNA-protective effects of dietary factors in humans: recent results and trends. Mutat. Res. 681, 68-79.

Holme, J. A., Morrison, E., Samuelsen, J. T., Wiger, R., Låg, M., Schwarze, P. E., Bernhoft, A. and Refsnes, M. (2003): Mechanisms involved in the induction of apoptosis by T-2 and HT-2 toxins in HL-60 human promyelocytic leukemia cells. Cell Biol. Toxicol. 19, 53-68.

Huff, W. E., Kubena, L. F., Harvey, R. B. and Doerr, J. A. (1988): Mycotoxin interactions in poultry and swine. J. Anim. Sci. 66, 2351-2355.

Hussein, H. S. and Brasel, J. M. (2001): Toxicity, metabolism, and impact of mycotoxins on humans and animals. Toxicology $167,101-134$.

Ihara, T., Sugamata, M., Sekijima, M., Okumura, H., Yoshino, N. and Ueno, Y. (1997): Apoptotic cellular damage in mice after T-2 toxin-induced acute toxicosis. Nat. Toxins 5, 141-145.

Jaradat, Z. W. (2005): T-2 mycotoxin in the diet and its effects on tissues. In: Watson, R. R. and Preedy, V. R. (eds) Reviews in Food and Nutrition Toxicity. Volume 4. CRC Press, Boca Raton. pp. 173-212.

Jaradat, Z. W., Vilá, B. and Marquardt, R. R. (2006): Adverse effects of T-2 toxin on chicken lymphocytes blastogenesis and its protection with vitamin E. Toxicology 225, 90-96.

Krska, R., Baumgartner, S., Josephs, R. and Fresenius, J. (2001): The state-of-the-art in the analysis of type-A and -B trichothecene mycotoxins in cereals. Anal. Chem. 371, 285-299.

Krska, R., Welzig, E. and Boudra, H. (2007): Analysis of Fusarium toxins in feed. Anim. Feed Sci. Technol. 137, 241-264.

Kruszewski, M., Iwaneńko, T., Bartłomiejczyk, T., Woliński, J., Starzyński, R. R., Gralak, M. A., Zabielski, R. and Lipiński, P. (2008): Hepatic iron content corresponds with the susceptibility of lymphocytes to oxidative stress in neonatal pigs. Mutat. Res. 657, 146-149.

Kuiper-Goodman, T., Scott, P. M. and Watanabe, H. (1987): Risk assessment of the mycotoxin zearalenone. Regul. Toxicol. Pharmacol. 7, 253-306. 
Lafarge-Frayssinet, C., DeCloitre, F., Mousset, S., Martin, M. and Frayssinet, C. (1981): Induction of DNA single strand breaks by T-2 toxin, a trichothecene metabolites of Fusarium, effect on lymphoid organs and liver. Mutat. Res. 88, 115-124.

Langseth, W. and Rundberget, T. (1998): Instrumental methods for determination of nonmacrocyclic trichothecenes in cereals, foodstuffs and cultures. J. Chromatogr. A 815, 103-121.

Liao, L. L., Grollman, A. P. and Horwitz, S. B. (1976): Mechanism of action of the 12,13epoxytrichothecene, anguidine, an inhibitor of protein synthesis. Biochim. Biophys. Acta 454, $273-284$.

Lovell, D. P. and Omori, T. (2008): Statistical issues in the use of the comet assay. Mutagenesis 23, 171-182.

Maenetje, P. W., de Villiers, N. and Dutton, M. F. (2008): The use of isolated human lymphocytes in mycotoxin cytotoxicity testing. Int. J. Mol. Sci. 9, 1515-1526.

Meek, I. B., Peplow, A. W., Ake, C. Jr., Phillips, T. D. and Beremand, M. N. (2003): Tri1 encodes the cytochrome $\mathrm{P} 450$ monooxygenase for C-8 hydroxylation during trichothecene biosynthesis in Fusarium sporotrichioides and resides upstream of another new Tri gene. Environ. Microbiol. 69, 1607-1613.

Mwanza, M., Kametler, L., Bonai, A., Rajli, V., Kovacs, M. and Dutton, M. F. (2009): The cytotoxic effects of fumonisin B1 and ochratoxin A on human and pig lymphocytes using Methyl thiazol tetrazolium (MTT) assay. Mycotox. Res. 25, 233-238.

Njobeh, P. B., Dutton, M. F., Koch, S. H., Chuturgoon, A. A., Stoev, S. D. and Mosonik, S. J. (2010): Simultaneous occurrence of mycotoxins in human food commodities from Cameroon. Mycotox. Res. 26, 47-57.

Östling, O. and Johanson, K. J. (1984): Microelectrophoretic study of radiation-induced DNA damage in individual mammalian cells. Biochem. Biophys. Res. Comm. 123, 291-298.

Pál, L., Dublecz, K., Weber, M., Balogh, K., Erdélyi, M., Szigeti, G. and Mézes, M. (2009): Effect of combined treatment with aflatoxin B1 and T-2 toxin and metabolites on some production traits and lipid peroxide status parameters of broiler chickens. Acta Vet. Hung. 57, 75-84.

Rafai, P., Tuboly, S., Bata, A., Tilly, P., Vanyi, A., Papp, Z., Jakab, L. and Tury, E. (1995): Effect of various levels of T-2 toxin in the immune-system of growing pigs. Vet. Rec. 136, 511-514.

Ré, J. L., De Méo, M. P., Laget, M., Guiraud, H., Castegnaro, M., Vanelle, P. and Duménil, G. (1997): Evaluation of the genotoxic activity of metronidazole and dimetridazole in human lymphocytes by the comet assay. Mutat. Res. 375, 147-155.

Schuhmacher-Wolz, U., Heine, K. and Schneider, K. (2010): Report on toxicity data on trichothecene mycotoxins HT-2 and T-2 toxins. CT/EFSA/CONTAM/2010/03, Question No. EFSA-Q-2010-0143, http://www.efsa.europa.eu/en/scdocs/doc/65e.pdf

Singh, N. P., McCoy, M. T., Tice, R. R. and Schneider, E. L. (1988): A simple technique for quantitation of low levels of DNA damage in individual cells. Exp. Cell Res. 175, 184-191.

Sokolović, M., Garaj-Vrhovac, V. and Simpraga, B. (2008): T-2 toxin: incidence and toxicity in poultry. Arh. Hig. Rada Toksikol. 59, 43-52.

Tice, R. R., Agurell, E., Anderson, D., Burlinson, B., Hartmann, A., Kobayashi, H., Miyamae, Y., Rojas, E., Ryu, J.-C. and Sasaki, Y. F. (2000): Single cell gel/comet assay: Guidelines for in vitro and in vivo genetic toxicology testing. Environ. Mol. Mutagen. 35, 206-221.

Varga, J. and Tóth, B. (2005): Novel strategies to control mycotoxins in feeds: A review. Acta Vet. Hung. 53, 189-203.

Venkatesh, P. K., Vairamuthu, S., Balachandran, C., Manohar, B. M. and Raj, G. D. (2005): Induction of apoptosis by fungal culture materials containing cyclopiazonic acid and T-2 toxin in primary lymphoid organs of broiler chickens. Mycopathol. 159, 393-400.

Weber, M., Stiller, Sz., Balogh, K., Wágner, L., Erdélyi, M. and Mézes, M. (2007): Effect of feeding T-2 toxin contaminated feed on the utilisation of vitamin $\mathrm{E}$ in chickens. Acta Vet. Hung. 55, 21-27. 